\title{
European Studies - Looking to the Future
}

\author{
PHILOMENA MURRAY ${ }^{1}$ \\ The University of Melbourne \\ pbmurray@unimelb.edu.au
}

\begin{abstract}
Research and teaching on Europe and on the European Union (EU) have grown exponentially in recent years, both within Europe and throughout the world. There has been increased breadth and depth of conceptual development and theorising. This article considers some challenges related to teaching and researching about the EU. It attempts to elaborate some agendas for scholars, in examining possible future directions for the study of Europe, both internationally and within Australia. The article examines the development of study of the EU and discusses the development of European Studies in Australia. It argues that the study of the EU and of Europe is increasingly dynamic, drawing on a variety of disciplines and sub-disciplines, within Australia and throughout the world.
\end{abstract}

\section{Introduction}

Research and teaching on Europe and on the European Union (EU) have grown exponentially in recent years, both within Europe and throughout the world. There has been increased breadth and depth of conceptual development and theorising. The EU has increased its membership, influence, scope and reach, presenting new challenges for analysis, a larger geographical area to cover and a more complex set of policy domains. The development of the EU's relations with the rest of the world has led to new conceptualisations of the EU's role and actorness and increased understanding of its interlocutors - including Australia. At the same time, there has been a growing interaction among disciplines, both within Europe and throughout the world. The need to diminish the barriers between disciplines and sub-disciplines and particularly what Peterson calls, in the context of political science analysis, 'phoney wars' between International Relations and Comparative Politics has been recognised and acted upon. ${ }^{2}$

\footnotetext{
${ }^{1}$ Philomena Murray is Associate Professor in the School of Social and Political Sciences, and Director of the Contemporary Europe Research Centre (CERC) at the University of Melbourne, where she holds a J ean Monnet Chair ad personam.

2 S. Hix, The Political System of the European Union, London, Macmillan, 1999.

J. Peterson, The choice for EU theorists: establishing a common framework for analysis,' European J ournal of Political Research Vol. 39, No. 3, 2001, pp. 289-318.

M. Pollack, 'International Relations Theory and European Integration', Journal of Common Market
} 
This article considers some challenges related to teaching and researching about the EU. It attempts to elaborate some agendas for scholars, in examining possible future directions for the study of Europe, both internationally and within Australia. The first part of the article examines the development of study of the EU and the second part discusses the development of European Studies in Australia.

\section{Conceptualising and Expanding the Study of the EU}

It is increasingly an accepted fact that there is no single theory of, or analytical approach to - the EU or the study of the EU known as 'European integration'. The scholarly skirmishes regarding different theoretical concepts have been superseded by virtual and actual round table debates on the appropriate conceptual or theoretical framework for various issues or events and by more sophisticated conceptualization. ${ }^{3}$ Peterson ${ }^{4}$ has suggested that EU scholars need to 'make choices about what they want to explain, and make the European Union a touchstone in the more general effort of political science to synthesise insights from comparative politics, international relations and public policy'. Egeberg 5 correctly argues that 'no single theory can adequately account for everything in this area'.

There are many ways to approach the study of the EU. Its depth and breadth and the fact that it is in flux - suggest that it has never belonged exclusively to one academic discipline or sub-discipline alone. The extension of the EU's policy remit; the expansion of its territory and increase in its tasks have all encouraged a wealth of approaches and multitude of concepts and theories. This has enriched the study of both the EU and of non-EU Europe and comprehension of integration and international affairs in a number of positive ways. There has been a considerable expansion of tasks for both scholars and students. The term task-expansion was utilized by an early observer of attempts at European cooperation, the neo-functionalist, Ernst Haas in The Uniting of Europe ${ }^{6}$ in his analysis of European integration. ${ }^{7}$

Further, the growth of both the EU and of the study of the EU rendered it incumbent on scholars to comprehend the historical underpinnings of the EU. This is critical to the understanding of the 27-member EU, whether it is

Studies, Vol. 39, No. 2, 2001, pp. 221-244.

C. Rumford and P. Murray, 'Globalization and the limitations of European Integration Studies: Interdisciplinary Considerations', J ournal of Contemporary European Studies, Vol. 11, No. 1, 2003a, pp. 85-93.

3 M. J achtenfuchs, The Governance Approach to European Integration', J ournal of Common Market Studies, Vol. 39, No. 2, 2001, pp. 245-264.

$4 \mathrm{~J}$. Peterson, 'The choice for EU theorists: establishing a common framework for analysis,' European J ournal of Political Research Vol. 39, No. 3, 2001, p. 313.

5 M. Egeberg, 'An organisational approach to European integration: Outline of a complementary perspective', European J ournal of Political Research Vol. 43 No. 2, 2004, pp. 199-219.

6 E. Haas, The Uniting of Europe, California, Stanford University Press, 1968.

7 T. A. Börzel, 'Mind the Gap! European Integration between Level and Scope', J ournal of European Public Policy Vol. 12 No 2, 2005, pp. 217-236. 
characterised as hybrid, mixed, or post-nationalist. 8 Further, the contemporary EU is a significantly different - and more important - actor than it was in the 1950s. This is reflected in the divergent approaches and increased multi-disciplinarity of contemporary EU studies and in the analysis of the EU as an international actor or global player in trade, aid, humanitarian assistance, conflict-prevention and conflict-management and normsexporting. These now feature in much of the research and curriculum on the EU9 and the study of the EU-interregional relations, for example with East Asia. ${ }^{10}$

In addition, the EU is a key focus of studies of climate change, terrorism and counter-terrorism, sub-national regionalism, identity studies, civilian protection, immigration, skills recognition, the Bologna process, vocational education and training, media and communication studies and many more areas that cross disciplinary boundaries.

Warleigh-Lack and Cini ${ }^{11}$ have recently drawn attention to the pressures for a turn towards interdisciplinarity, such as the search for new or more complete knowledge, responding to new issues that cross established disciplinary boundaries (climate change politics, for example), and the drive towards 'user focus' on the part of many research funders'. The advantages of an interdisciplinary approach to research were enunciated in the same article as: 'an escape from the increasing fragmentation of academia into sub-sub-subspecialisms'; the means for scholars to anchor their work in a wider range of debates and increase its viability and an opportunity to break out of the confines of a discipline; and advance ideas, values and ideology. ${ }^{12}$ These advantages mean that the study of the EU is no longer ghettoized ${ }^{13}$ and should not be confined to the study of 'integration' or European integration studies.

\section{Integration Studies or Area Studies or Europeanization Studies?}

The study of the EU has long been designated as either a form of European area studies or, increasingly, European Integration studies. More recently, the

\footnotetext{
8 A. Chalmers, 'Reconfiguring the European Union's Historical Dimension', European Journal of Political Theory, Vol. 5 No. 4, 2006, pp. 437-454.

9 I. Manners, 'Normative Power Europe: A Contradiction in Terms?', Journal of Common Market Studies, Vol. 40, No. 2, 2002, pp. 235-258.

Sjursen, Helene, 'What Kind of Power' J ournal of European Public Policy, Vol. 13, No. 2, 2006, pp. 169181.

10 B. Fort and D. Webber, (eds.), Regional Integration in East Asia and Europe. Convergence or Divergence? London; New York: Routledge, 2006.

P. Murray, (ed.), Europe and Asia: Regions in Flux, Basingstoke, Palgrave, 2008.

${ }_{11}$ A. Warleigh-Lack and M. Cini, 'Interdisciplinarity and the study of politics' European Political Science, Vol. 8, 2009, p. 4.

12 Ibid., pp. 9-10.

13 A. Sbragia, 'The European Community in English: a preliminary sketch', paper to The European Community after Maastricht Seminar, Research Committee on European Unification of the International Political Science Association, European Parliament, Luxembourg, Nov. 1993.

P. Murray, 'European Integration Studies: The Search for Synthesis', Contemporary Politics, Vol. 6, No. 1, 2000, pp. 19-28.
} 
study of the EU has been associated with the Europeanization. This section seeks to suggest that all of these designations have their problems.

The EU as area studies is understood as the study of a group of countries in one geographical area of the world and as the study of a regional entity. The first challenge for scholars in this context is that the EU is increasingly examined beyond its area or region, in its international role, in terms of its objectives in seeking to advance its regional integration agendas in a global context, for example. The second is that the EU's actions and regulations have extra-territorial impact - in multilateralism in trade negotiations and the UN, for example. The third is that the EU is no longer regarded as sui generis or as an 'N of One', as so many aspects are comparable. It is still, however, for many comparative regional integration specialists, regarded as a reference point or even paradigm for regional integration in other parts of the world. ${ }^{14}$ Fourthly, area studies have traditionally been the study of a number of countries that have some commonalities yet remain distinctively sovereign nation states. This is not the case in the analysis of the EU, where there is pooling of sovereignty and an established and embedded institutionalization of cooperation above the nation state. For all of these reasons, the term 'area studies' does not usefully describe the study of the EU.

The term European Integration Studies' is equally problematic. The study of the EU is considerably more than the study of integration processes and theories, for example. ${ }^{15}$ This has been recognised by those who seek to move beyond the comparative politics versus International Relations debates, the supranationalism versus intergovernmentalism debates and studies of individual policies. Phoney wars are ending but still there are many assumptions that tend towards normative or moralistic approaches, including the desire for a core curriculum regarding the EU. It can be argued that the term 'integration' is not useful to characterise the study of the EU and that the term has been exploited for so many purposes over the years that it has become almost meaningless and diminished in stature. ${ }^{16}$ European Integration refers to a long-term political project, which is often promissory, as well as policy processes, political goal and theory. It is the justification for EU policy actions and at the same time risks being justification for the lack of cogent intellectual action: it remains ill-defined.

The term 'integration' has also been utilised to explain many of the considerable changes and process that have taken place in Europe, regardless of whether it is part of the EU or due to the EU. Not everything that takes place within the EU is due to transformations wrought by the EU. ${ }^{17}$ There

14 P. Murray, 'Exporting a new public space? Reflections on the EU integration experience as a paradigm', European Political Science, vol. 7, no. 3, August, 2008, pp. 264-272.

P. Murray, 'Comparative Regional Integration in the EU and East Asia: Moving Beyond Integration Snobbery', International Politics, forthcoming, 2010.

${ }^{15}$ P. Murray, 'European Integration Studies: The Search for Synthesis', Contemporary Politics, Vol. 6, No. 1 , 2000, pp. 19-28.

A. Warleigh, 'Learning from Europe? EU Studies and the Re-thinking of 'International Relations", European J ournal of International Relations, Vol. 12, No. 1, 2006, pp. 31-51.

${ }^{16}$ P. Murray, 2009, 'Uses and abuses of the concept of integration', in C. Rumford ed., The Sage Handbook of European Studies, London, Sage, 2009, pp. 227-244.

${ }^{17}$ C. Rumford, and P. Murray, 'Do we need a core curriculum in European Union studies?', European Political Science, Vol. 3, No. 1, 2003b, pp. 85-92. 
have been transformations and synergies that have taken place on a number of levels and in trans-national contexts such as civil society; public spheres; public spaces; media; citizenship and cooperation among small and medium sized enterprises, for example.

The characterization of EU Studies as the study of Europeanization is gaining increasing leverage in the examination of the EU, particularly among scholars located within the EU itself. The transnationalism and interdependence of EU and of national administrative and governance systems form an important part of the ever-expanding literature on Europeanization, which can perhaps be regarded as a new means of examining the EU that does not focus exclusively on integration. Green, Cowles and Risse ${ }^{18}$ define Europeanization as involving the 'evolutions of new layers of politics that interact with older ones'. This may refer to the transformation of the nation state and of policy domains.

Scholars can usefully move towards an understanding of Europeanization as being a 'process' that is not just carried out by the EU but also involves the transformation of the EU by the member states and, cross-nationally, of member states by other member states - and, for example, Members of the European Parliament, in legislative and institutional socialization. In order to re-think the state and reassess how we understand power in the EU, we need to also re-examine our concepts of state, actorness, socialization and action. It is perhaps in this context that the study of the many facets of Europeanization can be advanced. Europeanization has both EU-to-member state and member state-to-EU level dynamics. However, the external impact of Europeanization also merits increased scholarly attention, in inter-regionalism, in the impact of the EU's regulatory regime and in its international agreements. The development of interdisciplinary approaches can encompass many of these concerns.

\section{Future Agendas}

The study of the EU can usefully be contextualized in a broader and more globalized context. ${ }^{19}$ For example, if the study of the EU is to be genuinely comparative, then comparative regional integration is a field of study of which the EU is simply one part - albeit an important one. There is a need to emphasise that the study of integration theory is not only about European integration processes and the EU but also comparative regionalism and interregionalism for example. ${ }^{20}$ In the context of Europeanization the transformation of the EU and its transformative impact on the state require

\footnotetext{
18 M. Green Cowles, J. Caporaso, T. Risse (eds.), Transforming Europe, Ithaca \& London, Cornell University Press, 2001, p. 3 and p. 217.

19 C. Rumford and P. Murray, 'Globalization and the limitations of European Integration Studies: Interdisciplinary Considerations', J ournal of Contemporary European Studies, Vol. 11, No. 1, 2003a, pp.85-93.

20 S. Breslin and R. Higgott, New regionalism(s) in the global political economy. Conceptual understanding in historical perspective', Asia EuropeJ ournal, Vol. 1, No 2, 2003, pp. 167-82.

B. Hettne and F. Soderbaum, Theorising the Rise of Regionness', New Political Economy; November Vol. 5, No 3, 2000, pp. 457-473.
} 
more examination. In addition, the study of the winners and losers in globalization need to be examined in the EU context - in the context of emerging cleavages in European party systems ${ }^{21}$ and in terms of the EU's globalisation compensation fund. National cleavages are increasingly accompanied by cleavages relating to the EU in national political party systems, and also related to the development of more distinctly European cleavages within the European Parliament. ${ }^{22}$ The distinction between national and European, between national and global, are all more fluid than in the past, revealing a rich research potential for scholars.

The study of the EU can be introspective in dealing with the EU's internal process and conflicts, for example. Examinations of the EU in an international context often tend to deal with its relations with individual countries and, occasionally, regions, such as the Association of South East Asian Nations (ASEAN) or Mercosur, the Common Market of South America. From outside the EU, some perspectives regard the EU as a rather successful economic entity but do not necessarily understand the transformative nature of the EU in political or normative terms. For example, J achtenfuchs ${ }^{23}$ has argued that the most exciting and most important aspect of European integration namely the transformation of traditional nation-states into constituent units of a new transnational political system that is not going to become a state - is largely overlooked from the outside'.

Transformation has been a feature of the EU since its origins. This is evident in the expansion and transformation of membership, scope, goals, institutional architecture, policy concerns and international impact. It is apparent in the altered interaction between nation states, which has led to altered dynamics of international diplomacy, trade relations, and the role of global actors. It is apparent in the ways that the EU has partly rewritten the international rule book for negotiations as it becomes an increasingly influential actor in global and multilateral forums, in trade, in aid and in its attempts to be a manager of globalization and a norms entrepreneur and norms exporter. This has been a significant transformation of sovereignty, as the EU rewrites the rule book of international diplomacy, international negotiations, regional integration and the EU role therein.

The EU has considerable external impact and extraterritorial influence and this warrants more attention from scholars than has occurred to date, a fact recognised by scholars on Europe in Australia and the Asia Pacific, as evidenced in recent scholarship and the creation of the Asia Pacific J ournal of EU Studies and the Asia Europe Journal. The EU is developing its global agenda, which is based on factors such as its history and memory of war and peace, its constitutionalising milestones, its economic might, its influence in the World Trade Organization and its efforts at international peacepromotion. This global dimension to the EU has not always led to fulsome praise and admiration throughout the world. There remains a perception of

\footnotetext{
21 W. Van Der Brug, J. Van Spanje, 'Immigration, Europe and the 'new' cultural dimension', European J ournal of Political Research, Vol. 48, Issue 3, May 2009, pp. 309-334.

22 S. Hix, The Political System of the European Union, London, Macmillan, 1999.

${ }^{23}$ M. Jachtenfuchs, The Governance Approach to European Integration', J ournal of Common Market Studies, Vol. 39, No. 2, 2001, p. 256.
} 
the EU as a Fortress Europe in many parts of the globe and this perception has arguably rendered it difficult to advance the study of the EU in some Australian contexts.

Thus, just as the EU's policy reach is not confined to Europe, neither are the influences upon it confined to its member states. The EU is not immune to the forces of globalization - and this understanding must be increasingly embedded in the study of the EU. 24 The global agenda advanced by the EU, especially since the 2001 Laeken European Council, situates the EU as a norm-exporter and even as a norms-enforcer based on civilian power instruments of sanctions, incentives, its influence on global governance norms and world trade norms.

In the future, scholars will continue to connect islands of theory and understanding. There will continue to be a fruitful dialogue between disciplinary specialists and area specialists. Increasingly new - and contested - understandings of the EU as a putative 'model', and of regionalism and regionalisation will emerge, especially in a comparative context. But comparison can be limited in scope if the centrality of the EU remains a key feature of comparative regional integration studies. The urge to conflate definitions and concepts must be resisted. The role of national interest will continue to be a dominant theme of the study of the EU - and of its relationship with its interlocutors.

The normative turn in the study of the EU has been beneficial in terms of opening a neglected window on the role of norms values and behaviour. The EU itself has presented itself as a type of normative actor, a growing area of scholarly concern in recent years. Yet the attempts by the EU to project an international political agenda are thus far under-researched. Much of the contemporary literature on the EU as an international actor continues to suffer from limited scope and a degree of path dependency. There remains a need to redress some of the limitations in scholarly analysis of normative power in Europe; to generate new conceptual tools and frameworks for the analysis of the EU as a political and global force; to provide a critical mirror for policymakers to understand the impact of their global actions on non-EU countries, including Australia; and to provide strategic insight into the EU's current global role for policymakers in non-EU countries, such as Australia, which has taken on board the need for training of its government officials regarding the EU. The latter two research concerns are of particular relevance to scholars of the EU in Australia and the Asia Pacific.

Finally, the changing role of governance has been a focus of considerable research in many languages across the EU and outside of the EU, in terms of the EU's attempt to advance it interpretation of global governance norms. It is worth noting that a recent Commission report on research on governance

24 C. Rumford and P. Murray, 'Globalization and the limitations of European Integration Studies: Interdisciplinary Considerations', J ournal of Contemporary European Studies, Vol. 11, No. 1, 2003a, pp. 85-93. 
and citizenship ${ }^{25}$ summarises the development of recent governance research agendas as follows:

Research on the very workings of the European institutions, the web of actors involved in deciding about the European 'res publica' and the involvement of citizens in this only started at European level in the late nineties ... By then, European research had advanced on a wide range of technological areas as well as on some 'collective goods' such as environment or health protection, and social science research had just started on some specific social problems such as education and social exclusion. A closer look, however, reveals that this development may not be that paradoxical, but rather reflects the evolution of European integration which was launched as a political project ... to be implemented through economic means and cooperation. Gradually political elements started gaining prominence ...'governance' emerged immediately as an important and contested topic for analysis.

Rosamond 26 approves of the move away from thinking about the EU in terms of integration, while retaining a concern about governance. He suggests that the literature on governance seeks to explore the extent to which politics and policy-making have been removed from the purview of the state and he sees an important role for governance studies, given international relations' 'emphasis on the EU as a complex international negotiating system' and the emphasis of comparative politics on the EU as a settled 'normal' political order, and so these approaches, for Rosamond, 'understate key elements of the distinctive and potentially transcendent character of the EU system'.

The role of the state has been central to studies of the EU. Rosamond, ${ }^{27}$ has illustrated that, from the 1950s onward, social scientists tended to regard the EU's precursor, the European Community, as a radical experiment with a central concern that of the role of the nation state in the process of constructing a supranational state. Integration, the self-conscious mission of European nation states, the nature, meaning and extent of which needed to be explained, while at the same time its objectives, were subject to change. ${ }^{28}$ Within the EU, the state has been transformed, and governance has been both transformed within the EU and transformed outside of the EU as part of the EU's global governance agenda.

\section{The Past and Future of European Studies in Australia}

Many of the issues and concerns elaborated above have been evident in research and teaching on Europe and the EU in Australian universities. The Contemporary European Studies Association of Australia (CESAA) was founded in March 1991 in response to a perceived need to bring together

\footnotetext{
25 European Commission, 'European Union Research on Governance and Citizenship' in the 6th Framework Programme and the first period of 7th Framework Programme. "Socio-Economic Sciences and Humanities" Programme, Brussels, 2008, p. 3.

26 B. Rosamond, 'Supranational Governance', in C. Rumford (ed.), The Sage Handbook of European Studies, London, Sage, 2009, pp.89-109

${ }_{27}$ B. Rosamond, Theories of European Integration, Basingstoke, Macmillan, 2000, p. 10.

${ }^{28}$ C. Rumford, and P. Murray, 'Do we need a core curriculum in European Union studies?', European Political Science, Vol. 3, No. 1, 2003b, pp. 85-92.
} 
specialists on Europe, to advance the study of Europe throughout Australian universities and to promote the understanding of Europe in the policy sphere. ${ }^{29}$ The establishment of CESAA was part of a world-wide trend to link Europeanists within nations and to cross national boundaries by establishing close relationships with other such organisations and the European Community Studies Associations (ECSA) network, based in Brussels. From the beginning, CESAA established a productive agenda of conferences; seminar series; a newsletter (later Review); an annual essay prize competition and a Register of European Studies. The first Register of European Studies of the Contemporary European Studies Association of Australia was compiled in 1993.30 Throughout the 1990s, European Studies in Australia developed with considerable success across a number of Universities, with the introduction of designated programmes. These programmes and courses covered Western Europe, the European Union, Scandinavia, Mediterranean Europe, Central and Eastern Europe and Russia.

It became evident from the activities of CESAA at the time and from the successive Registers ${ }^{31}$ that the study of 'Europe' ranged from the Faculties and Departments of political and social sciences through law and commerce to culture and languages. At the time, many universities had European Studies programs, at both undergraduate and postgraduate levels. European Studies Centres or European Research Centres in Australia in the 1990s included the Contemporary Europe Research Centre, The University of Melbourne; the Centre for European Studies, Monash University; the Centre for European Studies, the University of Adelaide; the Centre for European Studies, The University of New South Wales; the Centre for European Studies, The University of Sydney and the Centre for Scandinavian Studies, The Flinders University of South Australia. Fruitful links were established with the Australian Association of European Historians and the Australian Political Studies Association at this time.

On the research front, there was also considerable research being carried out on the EU and Europe, and the Australian Research Council awarded grants for research on the EC and EU and Central and Eastern Europe. For the first time, in 1996, the publication of the Worldwide European Community Studies Association (ECSA) entitled Who's Who in European Integration Studies included a chapter devoted to research in Australia, based on information from CESAA. ${ }^{32}$ In addition, the body of Australian research output on the EU gained international recognition when it was accorded a chapter in the Survey

\footnotetext{
29 The author was the founder President of CESAA.

30 C. Lonsdale, P. Murray, L. Topic, Register of European Studies in Australia, Contemporary European Studies Association of Australia, Melbourne, 1993.

31 P. Murray and T. Szlachetko, Register of Contemporary European Studies in Australia, Contemporary European Studies Association of Australia, Melbourne, 1998.

D. Horvath and F. Machin, with P. Murray and R. Wilson, Register of Contemporary European Studies in Australia, Melbourne, Contemporary European Studies Association of Australia, with Australian Universities Europe Network, and the Delegation of the European Commission, Canberra, 2004.

32 European Communities Studies Association, Who's Who in European Integration Studies, BadenBaden, Nomos Verlagsgesellschaft, 1996.
} 
of Current Political Science Research on European Integration Worldwide of the International Political Science Association. ${ }^{33}$

From its inception, CESAA brought together the European studies community of Australia and a number of visiting scholars in annual conferences and seminars. Many of the conference proceedings were published. ${ }^{34}$

In 1998, the first CESAA Workshop on European Studies took place, resulting in the publication of a very useful teaching resource. ${ }^{35}$ It became increasingly evident in more recent years that an assessment was required regarding how scholars research and teach about Europe and the EU, how they deal with the teaching-research nexus and how curriculum is developed. The first of a new series of National Workshops on European Studies in Australia was launched by the Contemporary Europe Research Centre at the University of Melbourne in conjunction with CESAA. It sought to assess the current state of European Studies in Australia and to examine future pathways in curriculum development. The issues that required attention included debates as to what is meant by European Studies; the state of European Studies in Australia and an analysis of the rewards and difficulties associated with the development of European Studies programs in Australia, particularly in an interdisciplinary context. The first workshop took place in August 2007 and the second on 30 May 2008. The first, entitled European Studies in Australia - Setting Further Agendas, brought together key scholars and covered comparisons between the status of European Studies in Australian universities ten years previously and its current status; challenges relating to student numbers in undergraduate and post-graduate European Studies programmes; and the degree to which European Studies is more than the study of the European Union. ${ }^{36}$ The attendance at these Workshops reflected a national cohort of specialists, drawn from the University of Melbourne, Monash University, Macquarie University, the Australian National University; Deakin University; La Trobe University; the University of New South Wales and Swinburne University. It was anticipated that future Workshops would take place on the role of languages in European Studies, strategies to attract European Studies research funding, and approaches to the teaching of European Studies (curriculum, focus on history, politics, economics etc.).

The workshop held in May 2008 focussed on the strengthening of European Studies in Australia. A roundtable of scholars showcased best practice and

33 P. Murray, 'Trends in Political Science Research on European Integration in Australia since 1991', in International Political Science Association: Survey of Current Political Science Research on European Integration Worldwide 1991-1994, Brussels, IPSA, 1994, pp. 267-276.

P. Murray, and T. Szlachetko, Trends in Political Science Research on European Integration in Australia since 1994', in International Political Science Association: Survey of Current Political Science Research on European Integration Worldwide 1994-1997, Brussels, IPSA, 1997.

34 See L. Holmes and P. Murray (eds.), Citizenship and Identity in Europe, Ashgate, Aldershot, 1999; P. Murray and L. Holmes (eds.), Europe - Rethinking the Boundaries, Ashgate, Aldershot, 199; P. Murray and L. Topic (eds.), Europe in the 1990s: Australia's Options, Contemporary European Studies Association of Australia, Melbourne, 1994; L. Hancock and C. O'Brien, Rewriting Rights in Europe, Hants., Ashgate, 2000.

35 A. Pavkovic and C. Welch with C. O'Brien (eds.), Teaching European Studies in Australia: problems and prospects: papers from the first CESAA workshop on teaching European Studies, Contemporary European Studies Association of Australia, Melbourne, 1999.

36 The papers presented are available at <http://www.cerc.unimelb.edu.au/events/Europeworkshop.html> 
discussed the opportunities and challenges in Australian universities. A second key focus of this workshop was on opportunities for educational collaboration between Australia and Europe and this session examined the funding opportunities available for both educational and research collaboration between Australia and Europe.

These Workshops have laid the ground for further fruitful development of scholarly collaboration and it is anticipated that future Workshops might address a number of themes. The first theme is the meaning of European Studies, whether it is the study of the EU; of non-EU Europe; of East and Central Europe; of one country in Europe or comparative studies of several European countries. A second theme is curriculum on European Studies in Australia. It could draw on debates relating to whether there is value in a core curriculum. It could address the issue of whether there are specific topics to be addressed in the Australian context - or an Asia Pacific one. What are the best applicable teaching methodologies in Australia? It would also address practical questions relating to hurdles encountered in establishing a European Studies Programme; the value of interdisciplinarityand the means to access EU financial and logistic support - and other support - for strengthening or creating European Studies programs.

A third theme is the nature of the research-teaching nexus ${ }^{37}$ and how is it developed in the study of Europe and the EU. Issues to discuss might include where research on individual countries fit in the EU context. It would draw on research on the EU as a global entity. Other issues of interest relate to what nation-state membership might mean for Europe, EU-Australia relations and EU-Asia relations. Other themes worthy of exploration are the debates regarding European borders, defining Europe and the potential limits to EU membership. This could relate to issues of European identity, such as ethnicity, religion and secularism, memory and the past and the possibility of a shared future.

Australia is placed in an interesting position where there are extensive linkages with colleagues in the Asia Pacific region as well as Europe and elsewhere and scholars in Australia have been involved in transnational research projects on the EU and Asia, for example 38 and in transnational projects regarding perceptions of the EU in the Asia Pacific, the first of which was a collaboration of the ECSAs of New Zealand, Australia, South Korea and Thailand. 39 The issue of EU-Australia relations is increasingly analysed within Australia, examining historical, trade, political and educational issues. ${ }^{40}$ This has received a new impetus with the 2008 Partnership

\footnotetext{
37 See, for example, the Centre for the Study of Higher Education (University of Melbourne), Griffith Institute for Higher Education (Griffith University) and Queensland University of Technology. (http://trnexus.edu.au/), The Teaching-Research Nexus: A guide for Academics and Policymakers in Higher Education, 2008.

38 P. Murray (ed.), Europe and Asia: Regions in Flux, Basingstoke, Palgrave, 2008.

39 N. Chaban and M. Holland (eds.), The European Union and the Asia Pacific: Media, public and elite perceptions of the EU, Abingdon, Routledge, 2008.

40 See P. Murray, Australia and the European Superpower: Engaging with the European Union, Melbourne, Melbourne University Press, 2005;

E. Papadakis, 'Australia and Europe: 1996-2000', in J. Cotton and J. Ravenhill (eds.), The National Interest in a Global Era: Australia in World Affairs 1996-2000, Melbourne, Oxford University Press, 2002.
} 
Framework and anticipated increased cooperation in the sphere of education. ${ }^{41}$ The Partnership Framework has as a key objective the strengthening of cooperation in science, research, technology and innovation, education and culture.

There remain challenges in establishing research and teaching projects in Australia. Yet, despite differences of distance, time zones, seasons and semesters, for example, scholars are tapping into a rich vein of co-operation and funding. ${ }^{42}$ Opportunities for cooperation with Europe and to draw on European funding over the last decade in particular have ranged from the J ean Monnet grants ${ }^{43}$ for research and teaching on the EU; the EU-Australia annual pilot mobility projects of over A\$1 million per year; Framework VII Research projects, Marie Curie and Erasmus Mundus as well as funding for the establishment of 'EU Centres'44. An important initiative in recent years has been the opportunity for Australian scholars to tap into the jointly-funded Australian government-European Commission pilot projects for student mobility, accounting for approximately $\$ 1$ million per annum. 45

\section{Concluding Remarks}

This is an exciting period for scholars in Australia and internationally, in terms of the development of conceptual and analytical tools and the development of research and curriculum - and a research-teaching nexus on a multiplicity of issues relating to historical period, country, length and experience of membership of the EU, and attitude to membership and external impact, for example. The EU has been examined as a possible regional state, ${ }^{46}$ a superpower, 47 a civilian power, ${ }^{48}$ a soft power and a

41 Department of Foreign Affairs and Trade/European Commission, EU-Australia Partnership Framework, Canberra, Brussels, 2008.

42 P. Murray, 'The EU and Australia: Beyond the Tyranny of Distance?' in P. Anderson and G. Wiessala (eds.), The EU and Asia: Reflections \& Reorientations, European Studies: A J ournal of European Culture, History and Politics, 25, Amsterdam, Rodopi, 2007, pp. 261-285.

43 Grants in Australia include one Jean Monnet Chair and one Personal Jean Monnet Chair; four Modules, one Centre of Excellence and two transnational research grants. The Contemporary Europe Research Centre at the University of Melbourne is a J ean Monnet European Centre of Excellence.

${ }^{44}$ In the last round, the following were awarded the EU Centre grants: the European and EU Centre, Monash University; the Innovative Research University Network Centre of La Trobe University, Macquarie University, Newcastle University, Griffith University, Flinders University and Murdoch University and the National Europe Centre in Canberra.

45 The completed pilot projects are, firstly, LEAFSE - Learning through Exchange - Agriculture, Food Systems and Environment (www.leafse.kvl.dk/). Consortium partners are: the Universities of Western Sydney; New England; Western Australia and Queensland; The Royal Veterinary and Agricultural University (KVL), Denmark; University of Wales; Wageningen University and Research Centre, The Netherlands; University of Kassel, Germany. The second pilot project is the Coursework Masters Exchange Programme in International Relations: A European-Australian Asia-Pacific Nexus (EAAPN) (www.gu.edu.au/school/gbs/ eaapn/). Consortium partners are: the University of Melbourne; Griffith University, Queensland; University of Queensland; Institut d'Etudes Politiques de Paris; University of Birmingham; University of Trento, Italy.

46 V. Schmidt, 'The European Union: Democratic Legitimacy in a Regional State?', J ournal of Common Market Studies, Vol. 42, No. 5, 2004, pp. 975- 997.

${ }^{47}$ M. Leonard, Why Europe will run the 21st Century, Fourth Estate, London and New York, 2005.

48 F. Duchene, 'Europe's Role in World Peace, in Mayne, Richard J. (ed.), Europe tomorrow: sixteen Europeans look ahead. London, Fontana, 1972.

I. Manners, 'Normative Power Europe: A Contradiction in Terms?', J ournal of Common Market Studies, Vol. 40, No. 2, 2002, pp. 235-258. 
metrosexual superpower 49 and with pertinent questions as to the nature of $\mathrm{EU}$ power generally. 50

The EU's significant economic and political weight has led to an increasing transformative effect on international agendas, for example through its ability to vote en bloc in international and multilateral forums. This has lead to a reevaluation of the EU's extra-territorial influence. There is a need to further examine the ways the EU has positioned itself as an international political actor and to assess its impact, whether in its broad foreign policy agenda or its role in global trade or as a development aid provider or as a norms exporter.

Finally, the EU experience of 'integration' has been regarded as a paradigm for other parts of the world, in particular the ASEAN and ASEAN Plus Three (China, Japan, South Korea) region. J ust as the term 'integration' is over-used within EU analysis, there is a danger that this tendency will be replicated in non-EU contexts too, as the EU is often admired as a model of regional integration. A further, worrying, aspect of this issue is the self-conscious efforts by some EU actors to advance the EU as a model not just of economic integration but also as a European Social model and as the manager of globalization and prototypical example of good governance, including both global governance and EU governance norms and values. ${ }^{51}$

The practice of examining the EU as a 'package' comprising the study of institutions, theories and policies - often as a type of core curriculum unfortunately still holds sway among some scholars of the EU, although it is becoming less dominant. The desire for a streamlined approach to the study of the EU - and for a core curriculum - must be resisted. ${ }^{52}$ It serves to stultify innovation, to limit interdisciplinarity, and to create an impression of a core group of experts who possess the holy grail of orthodoxy. The study of the EU and of Europe is increasingly dynamic, drawing on a variety of disciplines and sub-disciplines, within Australia and throughout the world.

\footnotetext{
I. Manners, Ian, 'Normative power Europe reconsidered: beyond the crossroads', J ournal of European Public Policy, Vol. 13, No. 2, 2006, pp. 182-199.

49 P. Khanna, The Metrosexual Superpower', Foreign Policy, J uly/ August 2004, pp. 66-68.

50 E.g. H. Sjursen, 'What Kind of Power' J ournal of European Public Policy, Vol. 13, No. 2, 2006, pp. 169-181.

${ }^{51}$ P. Murray, 'Comparative Regional Integration in the EU and East Asia: Moving Beyond Integration Snobbery', International Politics, forthcoming, 2010.

52 C. Rumford and P. Murray, 'Do we need a core curriculum in European Union studies?', European Political Science, Vol. 3, No. 1, 2003b, pp. 85-92.
} 